\title{
Social Construction on Use of Supplements in Two Urban Societies: Cases in Padang and Pekanbaru, Indonesia
}

\author{
Damsar $^{1}$, Indrayani $^{2}$ \\ \{damsar_aziz@yahoo.com¹, yaniindra@gmail.com² \\ Department of Sociology, Universitas Andalas, Padang, Indonesia ${ }^{1}$, Department of Management, \\ University of Batam, Batam, Indonesia ${ }^{2}$
}

\begin{abstract}
This Indonesian society is known as a plural society, both based on socioeconomic structure and ethnicity. Such pluralism will create a polarization in the use of supplements in various community groups how the use of supplements socially constructed in urban societies is a significant question in this study. To answer the question, a research was done in Padang and Pekanbaru with qualitative research method. In order to obtain primary data, there were in-depth interviews of 20 users of supplements and 2 persons from each carried "jamu" (traditional medicine) sellers, jamu shop owners, herbal sellers, "herbal home" owners, and fitness center managers or gym studio managers. In addition, observations were made on the activity of supplement transactions in each type of supplement trade. Data analysis used Miles and Huberman models. The results of the study showed that the use of supplements was socially constructed in a reference group. 4 reference groups construct the use of supplement patterns, namely traditional group, religious group, neoteric group, and rational group.
\end{abstract}

Keywords: the use of the supplement, social construction, urban society, plural society.

\section{Introduction}

Supplements are simply understood as something added to supplement to what has been consumed. Supplements, therefore, can be said to be added to foods, which contain one or more nutrients of vitamins, minerals, amino acids, fatty acids, and fiber. In addition, supplements can also be natural products such as herbs or non-plant natural ingredients, such as those obtained from animals [1]. Supplements are packed in tablet capsules, effervescent tablets, suction tablets, chewable tablets, soft capsules, granules, powders, pastilles, or in liquid products in the form of solutions, drops, or syrups.

Using a supplement is a social activity. Because the use of supplements by a person is seen as the acting individual attaches a subjective meaning to his behavior. His subjective meaning takes account of the behavior of others and is thereby oriented in its course. Weber [2] explained that social action, like all action, may be oriented in four ways. It may be: (1) instrumentally rational, that is, determined by expectations as to the behavior of objects in the environment and of other human beings; The expectations of the actor's own rationally pursued and calculated ends; (2) value rational, that is, determined by a conscious belief in the value for its own sake of some ethical, aesthetic, religious, or another form of behavior, independently of its prospects 
of success; (3) affectual (especially emotional), that is, determined by the actor's specific effects and feeling states; (4) traditional, that is, determined by ingrained habituation.

The use of supplements is a social activity that is associated with the body. Our bodies, according to Synnott [3], are contained by cultural, public and private symbols, positive and negative, political and economic, sexual, moral, and often controversial matter; likewise with the attributes, body functions, body condition, and senses. Height and weight, eating and drinking, sex, body shape and body language, various diseases that whack the body, all these are not just physical phenomena, they are also a social dimension. They are socially constructed [4], [5], [6].

The use of supplements is expected by the actors to make the body healthy, fit, beautiful, handsome, or mighty. Healthy, fit, beautiful, handsome, or mighty is the identity associated with the body. It not only affects the social response itself but also affects our chance of life ([3], [7]). Because of the importance of body identity in our lives it can be understood why people use supplements.

Using supplements is constructed in a social setting known as a society [8]. Indonesian society is built on the diversity of religion, culture, and socioeconomic status. Indonesian society, therefore, is also called as a plural society [9], [10], [11]). The pluralism is visible, especially, in urban communities. Such pluralism tends to form polarization in the use of supplements in different groups of society. It means that polarization in the use of supplements arises, grows, flowers or disappears in social interaction [12], [13].

In this regard, it is interesting to ask how the use of supplements socially constructed in urban communities, especially in Padang and Pekanbaru is? For that reason, how is the typology of supplement users?

\section{Research Methodology}

To This research was conducted in two cities of Indonesia, namely Padang and Pekanbaru. Padang is one of the old cities in Indonesia, which in the past was one of the most important port cities in Indonesia. Pekanbaru is a new city in Sumatra which development is relatively fast in Indonesia.

This research uses qualitative research method. Primary data were obtained through indepth interviews of 20 supplement users and 2 persons each from carried "jamu" (traditional medicine) sellers, jamu shop owners, herbal sellers, "herbal home" owners, and fitness center managers or gym studio managers. Moreover, some observations were conducted on the trading activities of the carried jamu sellers, jamu shop owners, herbal sellers, "herbal home" owners, and fitness center managers or gym studio managers.

\section{Results and Discussion}

\subsection{Reasons for the use of Supplements}

Based on the result of the research, there are differences of fundamental reasons between groups in society. Several reasons developed in the community why they are taking supplements, which are as follows:

One, the use of supplements as a tradition. The use of supplements is a habit that is passed from one generation to the next through the family. In this process, parents, especially mothers, 
play an important role in the process of habituation of children to consume supplements. Parents give examples of how to use supplements regularly. Parents also explain the benefits and functions of a supplement. In the process of habituation, parents do suggestions and persuasion so that children want to take supplements. The commercialization of tradition-based supplements reinforces the tradition through mass production. This commercialization caused the tradition to spread throughout Indonesia, marked by the establishment of many stalls or stands of tradition-based supplements in almost all cities of Indonesia. The next development is the presence of traders of tradition-based supplements, who trade across several corners of the city.

The second one is the use of supplements as religious teaching. The teachings of religion, especially Islam, provide guidance on how to live healthily. The use of supplements, therefore, refers to the Quran and Hadith. The personal reference of the implementation of the religious teachings on how to live healthily is the healthy living behavior of Muhammad, the prophet of the Muslims. For Muslims, what the prophet does, acts, eats, drinks, and makes is an example worthy and a model of his followers to imitate. The guidance is taught in various study groups. In the Quran it is advisable to drink honey, as described in QS An Nahl; 68-69: "Moreover, thy Lord taught the Bee to build its cells in hills, on trees, and in (men's) habitations; Then to eat of all the produce (of the earth), and find with skill the spacious paths of its Lord: Who give thought. "It was practiced by the Prophet, where he drank honey mixed with water every day when his stomach was empty. Another guidance that is often put forward in the study is the Hadith about drinking black cumin (nigella sativa). This hadith is narrated by al-Bukhari and Muslim, whose contents are as follows: Prophet Muhammad (peace and blessings of Allah be upon him) said: 'Use black cumin,' because in it there is a cure for all sorts of diseases except death.

The third is the use of supplements as a lifestyle. Lifestyle is one of the most important concepts put forward by Max Weber when explaining stratification in society. In Weber's view, there are three types of social stratification, the status groups, the classes, and the party. Status groups are seen as some people who are in status situations, that is, in common concerning honor and prestige. The equation in status is expressed through the style of life, characterized by the existence of privileges and monopolies of ideal and material goods and opportunities. It is shown through consumption style [14].

In the sociology of America, according to Abercrombie, Turner and Hill [15], lifestyle is the idea used to distinguish between rural and urban social life, as well as urban and peripheral areas. In recent work this concept has been used more broadly to characterize a particular group's tastes, attitudes, possessions or social behaviors that differentiate it from other groups. Thus the lifestyle is an aspect of consumer society: people buy lifestyles to distinguish them from others.

The urban lifestyle is related to the consumer society, the society in which the market governs human life. The urban lifestyle, therefore, is a market-driven lifestyle. What is eaten, drunk, used, worn, spent or inhaled, is constructed by capitalists who are the main exponents of the market. The level of beauty, for example, is valued by the market with the standards that the market has. The beauty of a person is judged by how white and sheen his face, how trim his body, or how many wrinkles on his face. To get a shiny white face, one can buy a variety of imported or local products or supplements with different types of price levels. Alternatively, also people can perform plastic surgery face to look beautiful. If you do not want plastic surgery, people can inject Botullinum Toxin A (botox) for some sides of his face. The side of the wrinkled face is tightened like a lip through the embroidered lips. When the eyebrows look less beautiful can be embellished through tattoos, embroidery, or painting with Henna. If you want to (look) slim, one can have many ways to achieve it. Multinational and local companies provide 
many options. Pharmaceutical and supplements companies provide a variety of drugs and supplements to shed fat in the body or make people always feel full do not want to eat a lot. If you do not like taking drugs or supplements, people can follow the weight loss exercise program or use the body slimming tool. Similarly, the degree of people's beauty is measured by market standards. People are said to be handsome when the hair is not dandruff, the face is not spotty or dark, the body does not smell unpleasant, the body must be athletic, or clothing should be branded. All men need to be handsome; the market provides it in the form of supplements, cosmetic products, and others [16].

So, if one wants to be beautiful, slim, dashing, mighty, and the like, then her reference is the construction of advertising about beauty, fitness, masculinity, and others. One way to achieve this is to use certain supplements. Massive attacks of advertising from various media communications, both conventional media such as television, newspapers and magazines, and on-line media, including social media, causee uniformity of meaning about beauty, fitness, virility, and the like. This uniformity of meaning facilitates the company of beauty, fitness, virility, and the like to construct the needs of people in the use of supplements.

The fourth is the use of supplements as a form of rationality. Users of supplements can also be caused because someone is experiencing malnutrition or certain substances needed by the body. Lack of nutrition or certain substances that the body needs can be based on real experience that is being experienced, such as a sore throat. Based on one's experience, for example, when taking vitamin $\mathrm{C}$ supplements then sore throat will disappear. Based on that experience, he will do the same in the present if the experience is the same as the past. Malnutrition or certain substances can be determined based on the results of laboratory or medical examination. Based on the results of the examination, the doctor or nutritionist advises using a supplement.

\subsection{Typology of Supplement Users}

The difference in the reasons for supplement use also illustrates the differences in supplemental groups of users. Supplement users, therefore, can generally be divided into four groups, namely traditional group, religious group, neoteric group, and rational group.

A traditional group is a group of insiders doing an action based on the traditions they have. They use tradition as a reference in acting. The existence of this group can be reconciled from the presence of tradition in the use of tradition-based supplements in society, especially jamu (traditional medicine). The tradition of drinking traditional medicine is a form of the existence of traditional groups, especially the community of Java and Madura. The Javanese introduced the tradition of drinking traditional medicine to the Indonesian people through intercultural interaction. The socialization of drinking traditional medicine occurs widely when national jamu companies advertise their products to the Indonesian people through various mass media such as radio, television, newspapers, magazines, and so on. At present in Padang and Pekanbaru, jamu users are not only from Javanese and Maduran communities but also from other communities such as Minangkabau, Sunda, Melayu, Batak, Bugis, Aceh, and Nias. Nonetheless, only Javanese families consistently socialize drinking herbal medicine to their family members.

The group considers jamu as "helping the treatment" rather than "for treatment". For this group, jamu is beneficial for increasing body stamina, body fitness, beauty, detoxification, and others. Based on user groups, jamu can be divided into 3 groups: jamu for all, jamu for women, and jamu for men. The traditional medicine for all is the most widely taken by both women and men. These herbs include jamu beras kencur, jamu kunyit (Curcuma domestica), jamu temulawak (Curcuma xanthorrhiza Roxb), jamu cabe puyang (Piper retrofractum Vahl and Zingiber aromaticu, Val), jamu sambiloto (Andrographis paniculata), and jamu tempuyung (Sonchus arvensis L). Jamu beras kencur is believed to increase appetite, relieve aches, increase 
stamina, and make the body become more fit. Jamu kunyit is regarded to relieve stomach pain, make skin brighter, relieve heat in, remove toxins from the body (detoxify, and lose weight). Jamu temulawak is perceived to increase endurance, relieve aches and symptoms of colds, and various diseases such as ulcers, headaches, kidney and bladder. Jamu cabe puyang is assumed can eliminate muscle pains, fever and tingling. Jamu sambiloto is believed to overcome stiff, increase appetite, lower cholesterol, prevent diabetes, reduce hhigh blood pressure, cleanse the blood, and get rid of acne. While jamu tempuyung is believed to destroy the kidney stone (nefrolitiasis).

While jamu for women, according to jamu sellers, has the most variant, because it is associated with the age and cycle of the life of women. The findings are the same as that found by Tilaar [17] about the variant of jamu for women. Because there are too many numbers and different naming based on jamu brand for women, simply, can be grouped into 4 kinds of jamu namely reproductive traditional medicine, treatment of traditional breast medicine, body slimming traditional medicine, and skin beauty traditional medicine. Therefore, not all jamu sellers provide or sell them. The jamu sellers, either kiosks or carried jamu sellers, usually only provide jamu according to consumer demand. When the consumer asks for a kind of jamu that is not provided by the seller, especially the carried jamu sellers, the seller will promise to provide for the next day. The jamu for women most desirable according to the sellers are jamu kunci suruh, jamu datang bulan, jamu galian singset, jamu pembayun, jamu uyup-uyup, and jamu galian rapet. Jamu kunci suruh is believed to eliminate leucorrhoea (fluor albus), to tighten the vagina, to eliminate body odor, shrink the uterus and stomach. Jamu datang bulan is regarded to normalize irregular menstruation, either late or too fast. Jamu galian singset is understood to make the body become slim. Jamu pembayun is trusted to be beautifying the breast. Jamu uyupuyup is perceived to increase the production of breast milk (mammary glands) while jamu galian rapet is believed to nourish the vagina and refresh the body, for slimming and glowing face.

Meanwhile, jamu for men consists of 2 types, namely strength jamu and healthy jamu. The user believes strength jamu can increase the ability of men in having sex overcome the problem of impotence. While healthy jamu is a traditional medicine that is believed to maintain fitness and stamina, especially for hard workers and athletes, each jamu manufacturer has a different name to traditional medicine. Differences in brands and names are not a problem for strong jamu consumers. For the most important is the function of jamu they consume.

A religious group is group of people who perform an act based on religious guidance. This study found that some of the followers of Islam use supplements concerning religious teachings, namely Quran and Hadith. This group can be referred to the history of its emergence on government policy to normalize campus life in the 1980s. The policy aims to sterilize student activities from politics so that student organizations on campus are disbanded and their activities abolished. In addition, the lecture system was changed from the package system to the semester credit system. This has an impact on the use of less free time so that students do not have much time to join the organization's activities off-campus.

This vacuum becomes an opportunity for the campus mosque to conduct Islamic studies among mosque congregations. The Islamic studies movement on campus started on a large campus in Java such as the University of Indonesia, Bandung Institute of Technology, and Bogor Agricultural University. This movement extended to other campuses in Java, Sumatra and Sulawesi in the early 1990s. Along with these developments, Islamic studies movement on campus experience friction in the focus, methods and ways in implementing Islam. Frictions that exist outside the campus also color the development of Islamic studies on campus. So on the campus appeared various fractions of Islamic studies such as Tarbiyah, Hizbut Tahrir, Salafi, and Jamaah Tabligh. 
At the community level, alumni from the Islamic studies movement on campus try to implement their study of Islam in everyday life. One of them is the implementation of a healthy life according to Islam, which became the reference is the Quran and Hadith. In addition to black cumin (nigella sativa) and honey, Prophet Muhammad once advocated the consumption of olive oil and dates. In the Hadith narrated by al-Baihaqi and Ibn Majah, the Prophet said: "Drink olive oil and oily with it because it is from a blessed tree." In other narrations, it is clear that the Messenger of Allah once said: "If you are rubbing (body) with olive oil, Devil will not approach you." While in Hadith Bukhari and Muslim, the Prophet said 'Whoever consumes Ajwah dates in the morning, then on that day he will not be exposed to poison or magic'. There are some other foods that are recommended for consumption such as pomegranate and lime. However, the most widely known supplements among this group are black cumin, honey, palm dates (Phoenix dactylifera), and olive oil. However, in its development, the four supplements are mixed in the form of new supplements such as between black cumin and honey, between olive oil and honey, between olive oil and dates, between black cumin, date palm and honey. This group does not distinguish between herbs for women and herbs for men.

How do users view their supplements? In general, users agree that black cumin is believed to warm the body, strengthen memory, normalize blood pressure, boost the immune system, detoxify, overcome diabetes, lower cholesterol, reduce uric acid, and prevent kidney stones. Olive oil is regarded to prevent breast cancer, skin cancer, colon cancer, and uterine cancer, lowering cholesterol, preventing hypertension, and dealing with worm diseases. While the date palm has long been known by the people of Indonesia, including the people of Padang and Pekanbaru, date palm is believed to reduce allergies and asthma, prevent bacteria, and cure a cough and sore throat. In addition to health, especially olive oil and honey is believed to add one's beauty.

In the beginning, the marketing of this type of supplement was carried out by the trader directly in the study group because he was a member of the group. Now there are already several herbal houses that sell a variety of herbal needs for this group, as well as selling other herbs. Although there have been many herbal plants, traders who sell in the recitation community still exist.

Neoteric group is a group in doing an action because it is influenced by lifestyle. This group emerged from the growing economic growth in the period leading up to the fall of the Suharto regime and continued especially after the economic crisis in 1998. Rapid development in various fields has spawned a new middle class in Indonesian society. They develop a new lifestyle that is influenced by the market.

This group can be divided into two types: lifestyle guidance and lifestyle impact. This type of lifestyle guidance means that lifestyle guides someone in using supplements. Neoteric groups of this type consume supplements because of the influence of the concepts of healthy, fit, beautiful, handsome, or mighty, which is constructed by the market. The construction uses a variety of advertising media such as television, radio, newspapers, magazines and online media. The image of healthy, fit, beautiful, handsome, or mighty represented from the stars of advertisements that are displayed. The construction is enhanced by testimonials from various actors who are seen as significantly affecting the audience.

While the type of lifestyle impact is people use supplements because of the impact of a particular lifestyle such as an alcoholic addict, a cigarette addict, and a vegetarian, the group realizes that their lifestyle does not fit the healthy and fit image of a healthy lifestyle. Therefore, to achieve a healthy and fit image, but still can maintain their lifestyle, then they use supplements. 
The market creates the need for various supplements that are considered "compulsory" to be consumed so that people can be healthy, fit, beautiful, handsome, or mighty. The market offers supplements with different types of products, brands, and prices. One trademark offers a wide variety of products, such as Sea-Quill. This brand offers 35 categories. Each category has at least two types of supplement products, such as supplements for anti-aging has two types of supplement products namely Sea-Quill Dhextion and Sea-Quill Melatonin. Like the traditional group, this group also found that there were supplements based on gender and age differences.

This group obtains supplements through a variety of ways: gym or gymnastics studio, online, pharmacy, drug store, and multi-level marketing (MLM). A particular fitness center or gym studio sells several types of supplements mainly related to body slimming and muscle forming. While buying in online, pharmacies, and drug stores, active buyers are looking for the supplements that are needed. Conversely when through multi-level marketing, active sellers offer to buyers.

A rational group is a group in performing an action based on rationality. This group takes action in consideration of expert advice or experience of a past event, which is also supported by existing knowledge and knowledge, including in taking supplements. When members of this group experience something uncomfortable with health, he or she goes to the doctor for advice on the situation. They use supplements at the advice of doctors or nutritionists against deficiencies of vitamins, minerals, amino acids, fatty acids, or fiber in their bodies. Once the need for nutrients or substances that the body needs is sufficient, they will stop taking supplements. The need for supplements in this group can be met by buying them in pharmacies or drugstores.

\subsection{Social Construction of Using Supplements}

From the results of the study showed that the use of supplements is a subjective action associated with others, in this case, the response of others and affect the chances of life, associated with the body. The subjective meaning that is owned is a reason for the use of supplements. There are four reasons people take supplements, which are traditional reasons, religious advice, follow the lifestyle, and the advice of a doctor or nutritionist. Differences of reasons indicate differences in existing groups. There are four groups of supplement users who are traditional groups for reasons of tradition, religious groups for reasons of religious guidance, neoteric groups with lifestyle reasons, and rational groups on the grounds of physician advice or nutritionist. Thus the reasons for the use of supplements in the form of benefits, functions, and uses associated with the body are constructed in the references group. The reasons are socialized, internalized and objectified through reference groups [8], [18].

Referring to Weber's account of the typology of social action [2], the four reasons include three types of social action, namely the reason for tradition as a traditional action, the reason for religious advice and following the lifestyle as value rational actions, or experts as an instrumentally rational action. This study found no affective action in taking supplements.

All the reasons for the use of supplements are related to the body; In order for him to be healthy, fit, beautiful, handsome, or mighty. The body, therefore, is an identity, a social self, and social situation that affects our lives [19], [20]. This is responded by the market by offering various types of supplements that match the reasons for the use of supplements. Not just responding, the market also creates a new need for supplements so that the use of supplements becomes a lifestyle [21].

The meaning of the body, in addition, is constructed through various reference groups that exist, also intervened by the market. The strength of the reference group can break market intervention to the meaning of the body. Many cases of supplements do not sell in the market 
because the meanings attached to the content of these supplements are negatively dimensional by religious authorities such as ulama.

\section{Conclusion}

The use of supplements is a social action, because of the subjective meaning or reason of an individual. Based on the subjective meaning or the reasons for the use of supplements there are four types of groups, namely traditional groups, religious groups, neoteric groups, and rational groups. Traditional groups have the following characteristics: tradition as a reason for consumption of supplements, jamu as supplements, and carried jamu sellers and jamu shop as the source of supplements. Religious groups have the following characteristics: religious teaching as the reason for the use of supplements, herbs according to religious teachings (habbatussauda, honey, date palm, and olive oil) as supplements, sellers in the religious study group and herb house as the source of supplements. The neoteric group is characterized as follows: lifestyle as the reason for consumption of supplements, branded and relatively expensive supplement products; As well as fitness centers or gymnasiums, online, pharmacies, drugstores, and multi-level marketing (MLM) as the supplement source. While the rational group is marked by the advice of a physician or an expert as a reason for the use of supplements, supplements prescribed or recommended by doctors or nutritionists, as well as drug stores or pharmacies as the source of supplements.

Social action takes place in social space, known as the reference group. Through the group is socialized, internalized, and objectified the importance of the use of supplements for the body.

\section{References}

[1] Murray, M. T. Encyclopedia of Nutritional Supplements. Rocklin, Calif.: Prima Pub., 1996.

[2] Weber, M. Economy and Society : An Outline of Interpretative Sociology. Berkeley: University of California Press, 1978.

[3] Synnott, A. The Social Body: Symbolism, Self, and Society. London: Routledge, 1993.

[4] Foucault, M. The History of Sexuality. Harmondsworth: Penguin, 1981.

[5] Laqueur, T. Making Sex: Body and Gender: From the Greeks to Freud. Cambridge, MA: Harvard University Press, 1990.

[6] Butler, J. Gender Trouble. London: Routledge, 1990.

[7] Bauman, Z. Identity. Cambridge: Polity, 2004.

[8] Berger, P. L. \& T. Luckmann, The Social Construction of Reality: A Treatise in the Sociology of Knowledge. Garden City, NY: Anchor Books, 1966.

[9] Furnivall, J. S. Netherlands India: A Study of Plural Economy, Cambridge: Cambridge University Press, 1939.

[10] Peacock, J. L. Plural society in Southeast Asia. The High School Journal, vol 56(1) pp. 1-10, 1972.

[11] Nasikun, Sistem Sosial Indonesia. Jakarta : PT Raja Grafindo, 2001.

[12] Damsar \& Indrayani, Pengantar Sosiologi Ekonomi. Jakarta: Prenadamedia, 2015.

[13] Lawang, R.M.Z. Kapital Sosial dalam Perspektif Sosiologik Suatu Pengantar. Depok: FISIP UI Press, 2004

[14] Damsar, Pengantar Teori Sosiologi. Jakarta: Prenadamedia, 2015.

[15] Abercrombie, N., B. Turner, and S. Hill, Kamus Sosiologi. Yogyakarta: Pustaka Pelajar, 2010.

[16] Damsar, Pengantar Sosiologi Perkotaan. Jakarta: Prenadamedia, 2017.

[17] Tilaar, M. Kecantikan Perempuan Timur. Jakarta: Indonesia Tera, 1999. 
[18] Adair, C. "Cultured bodies - the social construction of the body". In: Women And Dance. Women in Society Series List (ed CG). Palgrave, London, 1992, pp 24-39.

[19] Piliang, Y.A. Dunia yang Dilipat: Tamasya Melampaui Batas-Batas Kebudayaan. Bandung: Mizan, 1998.

[20] Turner, B. S. The body \& Society. London: Sage, 1996.

[21] Piliang, Y.A. Posrealitas: Realitas Kebudayaan dalam Posmetafisika. Bandung: Jalasutra, 2004. 